\title{
Ogólnopolska Konferencja Naukowo-Metodyczna pt.: „Między tradycją a współczesnością. W stronę aktywizujących metod nauczania historii wychowania" Gdańsk 1-2 grudnia 2008 r.
}

Konferencja zorganizowana została przez Instytut Pedagogiki, Zakład Historii Nauki, Oświaty i Wychowania oraz Koło Naukowe Historyków Edukacji Uniwersytetu Gdańskiego. Było to już drugie $\mathrm{z}$ cyklu spotkań poświęconych metodyce nauczania historii wychowania - pierwsze odbyło się w listopadzie 2007 r. pod tytułem „Akademicka 'burza mózgów'".

Konferencję otworzył prof. Romuald Grzybowski - Dyrektor Instytutu Pedagogiki Uniwersytetu Gdańskiego. Przywitał on wszystkich gości. Następnie zwrócił się do mgr. Mariusza Brodnickiego - opiekuna Koła Naukowego Historyków Wychowania oraz inicjatora tematyki spotkań gdańskich, dziękując mu za tak istotne przedsięwzięcie, jakim jest prezentacja i analiza problemów związanych $\mathrm{z}$ dydaktyką historii wychowania.

W rozważaniach na temat istoty przedmiotu Konferencji, prof. Grzybowski zaakcentował związek pomiędzy nauczycielem a uczniem, podkreślając rolę nauczyciela nie jako biernego obserwatora, czy wręcz inżyniera, ale jako czynnie zaangażowanego inicjatora procesu dydaktyczno-wychowawczego i jego twórcę. Zwrócił uwagę na ogromne znaczenie osobowości nauczyciela, który powinien być człowiekiem bogatym wewnętrznie i ,jak Św. Mikołaj - mieć wiele do rozdania".

W pierwszej części Konferencji, pod przewodnictwem prof. Wiesława Jamrożka z Uniwersytetu im. A. Mickiewicza w Poznaniu, pierwsze zabrały głos prof. dr hab. Lucyna Preuss-Kuchta oraz mgr Joanna Król - Mazurkiewicz z akademii Pomorskiej w Stupsku. Przedstawiając temat: „(Do)budowanie wiedzy. Student - jej odbiorca i badacz", referentki dokonały analizy pracy studenta, który może być z jednej strony badaczem, z drugiej - odbiorcą. Starały się rozstrzygnąć, czy wiedza jest dla studenta wartością, substytutem, czy suplementem.

Referat pt. „Między celami przedmiotu a dążeniem do obiektywizmu oceniania”, zaprezentowała dr Grażyna Szyling z Uniwersytetu Gdańskiego. Ukazując implikacje wypływające $\mathrm{z}$ aktywizujących metod nauczania, Referentka pozostawiła słuchaczy $\mathrm{z}$ refleksją na temat rodzajów kryteriów oceny z takim nauczaniem związanej.

„Rola diagnozy w kształceniu studenta” - to temat wystąpienia dr Marii Groenwald (z Uniwersytetu Gdańskiego). Przedstawiając rożne aspekty diagnozy, zwraciła uwagę na konieczność dostrzeżenia indywidualności studenta. Zadbanie o użyteczność diagnozy, to warunek, który przekłada się na wszechstronny rozwój osobowości studenta. W podsumowaniu dr M. Groenwald podkreśliła, że to przede wszystkim nauczyciele ponoszą odpowiedzialność za jakość kształcenia, a nie metody, które stosują.

Dr Małgorzata Wiśniewska oraz dr Aneta Niewęglowska (z Akademii Podlaskiej) przedstawiły temat „Poglądowość i aktywność - podnoszeniem efektywności procesu kształcenia w zakresie historii wychowania". Referentki zwróciły uwagę na fakt, że najbardziej zapamiętujemy, gdy jesteśmy w procesie uczenia aktywni. Badania, które Panie przeprowadziły, wykazały, że najskuteczniejszą formą zapamiętywania wiedzy przez stu- 
dentów jest łączenie słowa $\mathrm{z}$ obrazem. Badani studenci ocenili przekaz multimedialny i dyskusję jako najskuteczniejsze metody przyswajania wiadomości.

W drugiej części obrad, prowadzonych pod przewodnictwem prof. Kazimierza Puchowskiego z Uniwersytetu Gdańskiego, cykl wystąpień rozpoczął mgr Krzysztof Jaroń (z UG) tematem „Interpretacja historii a historia interpretacji: Nietsche i historia”. Referent podkreślił, że podmiot interpretujący historię powinien wykorzystywać ją do podtrzymywania życia, do rozumienia siebie, kreować sens życia.

„Teleologiczne podstawy nauczania historii wychowania w opinii studentów Akademii Pomorskiej w Słupsku" stanowiły temat wystąpienia dr Danuty Apanel (z Akademii Pomorskiej). Autorka, na podstawie przeprowadzonych wśród studentów badań ankietowych na temat m.in. świadomości celu nauczania historii wychowania, przedstawiła korzyści, na które wskazywali respondenci.

Mgr Elżbieta Okroy (z UG), referując temat „Przestrzenie pamięci - historia - wychowanie", zaprezentowała problematykę pamięci jako przedmiot zainteresowań historii wychowania. Zwróciła m.in. uwagę na konieczność odejścia od typowych, tradycyjnych metod zapamiętywania na rzecz aktywnego poznawania wiedzy. „Negocjacje historii M. Foucault i G. Deleuze" - to z kolei temat prezentacji mgr Ewy Okroy (z UG). Referentka zwróciła uwagę na edukacyjną funkcję kultury oraz wpływ różnorodnych czynników na rozwój historii wychowania.

Mgr Magdalena Boczeń (z UG) przedstawiła temat „W poszukiwaniu genezy i zasadności dialogu w edukacji". Referentka w rozważaniach na temat zasadności dialogu w edukacji, cofnęla się do czasów antyku, odwołując się do sofistów, Sokratesa, Platona, Arystotelesa. Ukazując dzieje retoryki, wyeksponowała zarazem tendencje w rozwoju dialogu.

Dr Elżbieta Gorloff (z UG) w wystąpieniu na temat „Media a kształcenie i studiowanie historii wychowania" zwróciła uwagę m.in. na konieczność wykorzystania technologii informacyjnych w kształceniu. Podkreśliła, że należy kształtować wśród studentów krytyczne i selektywne podejście do dostępnych materiałów. Dr E. Gorloff wskazała na wiele interesujących, autoryzowanych portali specjalistycznych zawierających bogaty materiał merytoryczny.

„Ewolucja tożsamości historii wychowania w kontekście tożsamości pedagogiki” była tematem wystąpienia dr Izabeli Stelmasiak (Z Akademii Pomorskiej). Referentka podkreśliła m.in. konieczność ukazywania w pedagogice jej kontekstu historycznego.

Doskonałym przełożeniem rozważań na temat aktywizujących metod nauczania historii wychowania były warsztaty, które, przeprowadzone pod przewodnictwem mgr. Mariusza Brodnickiego, zdominowały drugi dzień konferencji. Były one wspaniałym doświadczeniem praktycznym, wskazującym na wiele interesujących sposobów prowadzenia zajęć. 